\title{
HUMAN NEUTROPHILS EXHIBIT DISPARATE CHEMOTACTIC FACTOR GENE EXPRESSION
}

R. M. Strieter, K. Kasahara*, R. Allen*, H. J. Showell**, T. J. Standiford, and S. L. Kunkel*

Departments of Medicine and *Pathology, University of Michigan Medical School, Ann Arbor, Michigan

**Department of Immunology, Pfizer Central Research, Groton, Connecticut

Received November 2, 1990

The evolution of acute inflammation from initiation through resolution is associated with the changing character of the infiltrating leukocytes. Recruitment of these leukocytes is dependent upon the generation of chemotactic factors that have either global or specific activity for a particular leukocyte. In this manuscript we present data demonstrating that human neutrophils can express mRNA for neutrophil chemotactic factor/interleukin 8 (IL-8), but fail to express mRNA for monocyte chemotactic protein (MCP-1). The expression of IL-8 was observed upon adherence or in response to stimulation with lipopolysaccharide. Maximal IL-8 antigenic production was noted at $24 \mathrm{hrs}$. These studies demonstrate a disparate expression of chemotactic cytokines by neutrophils. O 1990 Academic Press, Inc.

Inflammation is a highly coordinate event which depends upon the sequential arrival of inflammatory leukocytes to the site of inflammation. This temporal recruitment of leukocytes is characteristic of an evolving inflammatory event. The elicitation of these leukocytes is dependent upon the generation of humoral mediators/chemotaxins. These chemotactic factors are diverse and possess varying specificity for leukocytes. Chemotactic factors such as $\mathrm{C} 5 \mathrm{a}$, leukotriene $\mathrm{B}_{4}$ (LTB4), platelet-activating factor (PAF), and the bacterial-derived peptides (FMLP) have all been shown to be chemotactic for both neutrophils and monocytes (1-4). Hence, redundancy exists for the mechanisms involved in leukocyte recruitment. Recently, two novel chemotactic cytokines, neutrophil chemotactic factor/interleukin 8 (IL-8) and monocyte chemotactic protein (MCP-1) have been isolated, purified, cloned and expressed $(5,6)$. IL-8 and MCP-1 are derived from a variety of immune and nonimmune cells (5-7), and demonstrate chemotactic specificity for neutrophils and monocytes, respectively (5-7).

Neutrophil sequestration is the hallmark of acute inflammation. Although the neutrophil can participate in the inflammatory process by the release of reactive oxygen metabolites, preformed proteases, and lipid chemotaxins (LTB4 
and PAF), it has previously been considered a terminally differentiated cell with limited ability to synthesize de novo protein. Recently, however, the neutrophil has been shown to synthesize and express a number of cytokines, such as TNF $\alpha$, IL-1, IL-6, G-CSF, M-CSF, and IFN $\alpha$ (8-12).

In this study, we demonstrate that highly purified (>99\%) human neutrophils can express IL-8 mRNA in response to adherence or stimulation with lipopolysaccharide (LPS). IL-8 antigen was determined by a sensitive IL-8 ELISA and was maximal at $24 \mathrm{hrs}$. In contrast, these neutrophils failed to express specific mRNA for MCP-1. These studies suggest that the neutrophil is a pivotal cell for the elicitation of additional leukocytes to an area of inflammation.

\section{Materials and Methods}

Cell Preparation: Human neutrophils were obtained from heparinized venous blood of healthy volunteers by ficoll-hypaque centrifugation followed by sedimentation in $5 \%$ dextran $/ 0.9 \%$ saline (Sigma). Neutrophils were separated from erythrocytes by lysis in a solution of $0.15 \mathrm{M} \mathrm{NH}_{4} \mathrm{Cl}, 0.01 \mathrm{M} \mathrm{NaHCO}_{3}$, and 0.01 $M$ tetra EDTA. The recovered neutrophils were resuspended in RPMI 1640 (Whitaker Biomedical Products) containing $1 \mathrm{mM}$ glutamine, 25mM HEPES, 100 $\mathrm{U} / \mathrm{ml}$ penicillin, and $100 \mathrm{ug} / \mathrm{ml}$ streptomycin (Hazelton Biomedical Products) (complete media) and washed 3 times. Neutrophils were greater than 99\% pure and greater than $95 \%$ viable by trypan blue exclusion. The cells in complete media were plated in $60 \mathrm{~mm}$ plates (Costar) at a concentration of $5 \times 10^{6}$ cells $/ \mathrm{ml}$. Reagents: Stock LPS (Escherichia coli 0111:B4; Sigma) was prepared at a concentration of $200 \mathrm{ug} / \mathrm{ml}$ of complete media. Stock cycloheximide was prepared at a concentration of $1 \mathrm{mg} / \mathrm{ml}$ in DMSO.

Northern blot analysis: Total cellular RNA (2 X $10^{7}$ cells) was extracted as previously described (13). Briefly, neutrophils were solubilized in a solution of 25 $\mathrm{mM}$ Tris, pH 8.0 containing $4.2 \mathrm{M}$ guanidine isothiocyanate, $0.5 \%$ Sarkosyl, and $0.1 \mathrm{M}$ beta-mercaptoethanol. After homogenization, an equal volume of $100 \mathrm{mM}$ Tris, $\mathrm{pH} 8.0$ containing $1.0 \%$ SDS and $10 \mathrm{mM}$ EDTA was added and the RNA extracted with chloroform-phenol followed by chloroform-isoamyl alcohol. The RNA was alcohol precipitated and separated by formaldehyde/1\% agarose gels and transblotted to nitrocellulose. The baked blots were prehybridized and hybridized with 32P-5'-end-labeled, 30-mer oligonucleotide probes. The probes were complementary to either nucleotides 256-285 of published cDNA sequence for human monocyte chemotactic and activating factor/monocyte chemoattractant protein $(14,15)$ or nucleotides 262-291 of published cDNA sequence for neutrophil chemotactic factor (IL-8) (16). The sequence of MCP-1 probe was 5'-TTG-GGTTTG-CTT-GTC-CAG-GTG-GTC-CAT-GGA-3', while the sequence for the IL-8 probe was 5'-GTT-GGC-GCA-GTG-TGG-TCC-ACT-CTC-ATT-CAC-3'. Blots were stringency washed and autoradiographs were quantitated by laser densitometry. Equivalent amounts of total RNA loaded per gel lane were assessed by monitoring $28 \mathrm{~s}$ and $18 \mathrm{~s}$ rRNA.

IL-8 ELISA: Antigenic IL-8 was quantitated using a double ligand ELISA method, as previously described (13). This ELISA method consistently detected IL-8 concentrations above $30 \mathrm{pg} / \mathrm{ml}$.

Statistical analysis: Data are expressed as means +/- SEM. Groups of data were evaluated by analysis of variance. Data that appeared statistically significant were compared by Student's $t$-test for comparing the means of multiple groups, and considered significant if $\mathrm{p}<0.05$. 


\section{Results}

Chemotactic Cytokine Gene Expression by Human Neutrophils. Previously we had demonstrated that IL- 8 and MCP-1 steady-state mRNA levels are maximal between 4 and $8 \mathrm{hrs}$. (17-19). Thus our initial studies were designed to assess the ability of neutrophils to express mRNA specific for these chemotactic cytokines at a similar time. Figure 1 shows the Northern blot of total RNA isolated from neutrophils in suspension (after purification), or neutrophils cultured for $4 \mathrm{hrs}$ in the presence or absence of $100 \mathrm{ng} / \mathrm{ml}$ of LPS. Neutrophils that had been cultured demonstrated significant steady-state levels of mRNA for IL-8 as compared to cells in suspension, suggesting de novo gene expression. LPS treatment resulted in an approximately $46 \%$ greater steady-state levels of IL-8 mRNA as compared to unstimulated neutrophils. In contrast, MCP-1 mRNA was undetectable upon either adherence or post-LPS-stimulation. Similar findings were seen at $8 \mathrm{hrs}$, after which a significant decay in IL-8 mRNA was noted (data not shown).

Human Neutrophil-Derived Antigenic IL-8. Since neutrophils had the apparent capacity for gene expression of IL-8, but not MCP-1, we next examined their

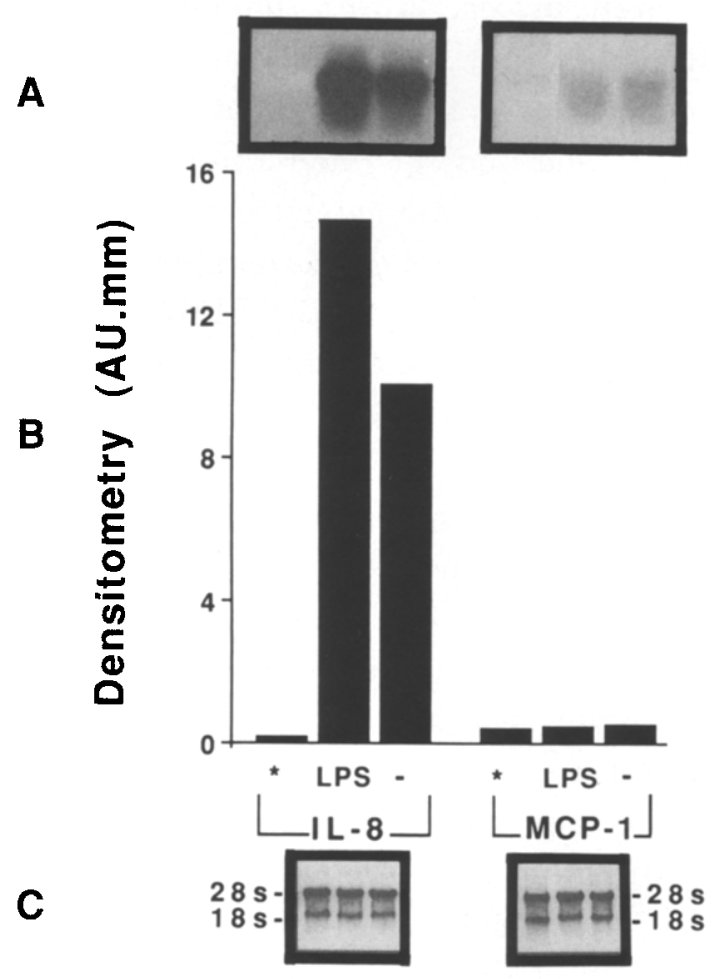

Figure 1. Northern blot analysis of neutrophil-derived chemotactic cytokine mRNA. A) is the Northern blot of steady-state levels of IL-8 and MCP-1 mRNA at $4 \mathrm{hrs.}, \mathrm{B})$ and $\mathbf{C}$ ) are the laser densitometry and $28 \mathrm{~s}$ and $18 \mathrm{~s}$ rRNA for the corresponding Northern blots in $\mathbf{A}$, respectively. The times for autoradiographic development of the Northern blots in $\mathbf{A}$ were 8 and 24 hrs. for IL- 8 and MCP-1, respectively. 
Table I

\begin{tabular}{llll}
\hline & Unstimulated & LPS $(100 \mathrm{ng} / \mathrm{ml})$ & p-value \\
\hline IL-8 $(\mathrm{pg} / \mathrm{ml})$ & $39+/-6.4$ & $100.3+/-21.6$ & 0.01
\end{tabular}

Neutrophil-derived IL-8 antigen at $24 \mathrm{hrs}(\mathrm{n}=6)$.

ability to generate IL-8 antigen. Neutrophils in the presence or absence of LPS (100 ng/ml) were cultured and supernatants harvested at various time intervals. As shown in Table I, neutrophils cultured for $24 \mathrm{hrs}$ demonstrated maximal IL-8 antigenic production. LPS-treated neutrophils produced $100.3+/-21.6 \mathrm{pg} / \mathrm{ml}$ of IL8 , a 2.6 fold increase over unstimulated cells. This LPS-induced neutrophilderived IL-8 was statistically greater $(\mathrm{p}<0.05)$ than unstimulated cells. Neutrophils cultured with cycloheximide $(5 \mathrm{ug} / \mathrm{ml})$ in the presence or absence of LPS did not produce detectable levels of IL-8 (data not shown).

\section{Discussion}

The proximal event associated with the initiation of acute inflammation is the influx of neutrophils. This neutrophilic accumulation greatly exceeds the emigration of monocytes. As the inflammatory process evolves, monocytes continue to accumulate and undergo differentiation into macrophages, whereas neutrophils die or leave the inflammatory site via lymphatics. This dynamic change in the cellular characteristic of acute inflammation is due to a myriad of chemotactic factors, most of which possess little specificity for a particular leukocyte. Recent studies have demonstrated that a novel class of chemotactic cytokines exist that exhibit specific chemotactic activity for inflammatory leukocytes. MCP-1 is a potent chemoattractant and activating factor for monocytes, while IL-8 possesses specific chemotactic activity for neutrophils and lymphocytes $(5-7,20)$. This latter effect is of particular interest since the local concentration of IL-8 is important in determining whether neutrophils or lymphocytes are predominantly elicited, as IL-8 is 10 to 100 fold more potent as a chemotaxin for lymphocytes as compared to neutrophils.

The neutrophil, the major cellular constituent of acute inflammation can no longer be viewed as only a phagocyte or warehouse for proteolytic enzymes. Monocytes and neutrophils share the same stem cell, and like monocytes, neutrophils have the same capacity to phagocytize or kill bacteria via various proteases and reactive oxygen metabolites. In addition to these functions, recent studies have shown that the neutrophil can produce various cytokines, such as TNF $\alpha$, IL-1, IL-6, G-CSF, M-CSF, and IFN $\alpha$ (8-12). The production of these cytokines by neutrophils at sites of inflammation may play a significant role in the subsequent evolution of either acute or chronic inflammation. 
We now describe another neutrophil-derived cytokine, IL-8. Our results show that neutrophils are capable of synthesizing and secreting IL-8. To exclude the presence of preformed neutrophil-derived IL-8, neutrophils were shown to express de novo mRNA specific for IL-8. This IL-8 gene expression was of neutrophil origin, since less than $1 \%$ monocyte contamination of the neutrophil cultures would not explain the magnitude of IL-8 mRNA accumulation. These data corroborate our previous findings with regard to disparate production of IL-8 and MCP-1 by monocytes and alveolar macrophages (21). The inability of these cells to produce MCP-1 emphasizes the importance of MCP-1 production by endothelial cells and fibroblasts (22). Furthermore, the production of neutrophilderived cytokines may influence subsequent cell-mediated immunity. Both IL-1 and TNF $\alpha$ have established immunoregulatory function in lymphocyte activation and proliferation. Thus, the neutrophil could conceivably orchestrate the conventional immune response through not only the generation of TNF $\alpha$ and IL1 , but also the production of a lymphocyte chemotaxin, IL-8.

Acknowledgments: This work was supported in part by NIH grants HL31693, HL35276, HL02401, and DK38149. Additional support was provided by the Council on Tobacco Research and American Lung Association. Dr. Strieter is a RJR Nabisco Research Scholar.

\section{References}

1. Fernandez, H. N., Henson, P. M., Otani, A., Hugli, T. E. (1978) J. Immunol. 120, 109-19.

2. Bray, M. A., Ford-Hutchinson, A. W., Smith, M. J. H. (1981) Prostaglandins 22, 213-19.

3. Braquet, P., Touqui, L., Shen, T. Y. (1987) Pharmacol. Rev. 38, 97-129.

4. Showell, H. J., Freer, R. J., Zigmond, S. H., Schiffman, E., Aswanikumar, S., Corcoran, B., Becker, E. L. (1976) J Exp. Med. 143, 1154-65.

5. Matsushima, K., Oppenheim, J. J. (1989) Cytokine 1, 2-13.

6. Baggiolini, M., Walz, A., Kunkel, S. L. (1989) J. Clin. Invest. 84,1045-49.

7. Kunkel, S. L., Chensue, S. W., Strieter, R. M., Lynch, J. P., Remick, D. G. (1989) Am. J. Respir. Cell Mol. Biol. 1, 439-47.

8. Dubravec, D. B., Spriggs, D. R., Mannick, J. A., Rodrick, M. L. (1990) Proc. Natl. Acad. Sci. USA 87, 6758-61.

9. Tiku, K., Tiku, M. L., Skosey, J. L. (1986) J. Immunol. 136, 3677-85.

10. Cicco, N. A., Lindemann, A., Content, J., Vandenbussche, P., Lubbert, M., Grauss, J., Mertelsman, R., Herrman, F. (1990) Blood 10, 2049-52.

11. Lindemann, A., Riedel, D., Oster, W., Zielgler-Heitbrock, H. W., Mertelsmann, Herrman, F. (1989) J. Clin. Invest. 83, 1308-12.

12. Shirafuji, N., Matsuda, S., Ogura, H., Tani, K., Kodo, H., Ozawa, K., Nagata, S., Asano, S., Takaku, F. (1990) Blood 75, 17-19.

13. Standiford, T. J., Strieter, R. M., Chensue, S. W., Westwick, J., Kasahara, K., Kunkel, S. L. (1990) J. Immunol. 145, 1435-39.

14. Yoshimura, T., Naoya, Y., Moore, S. K., Apella, E., Lerman, M. I., Leonard, E. J. (1989) FEBS Letters 244, 487-93.

15. Furutani, Y., Nomura, H., Notake, M., Oyamada, Y., Fukui, T., Yamada, M., Larsen, C. G., Oppenheim, J. J., Matsushima, K. (1989) Biochem. Biophys. Res. Comm. 159, 249-255. 
16. Matsushima, K., Morishita, K., Yoshimura, T., Laver, S., Kobayashi, Y., Lew, W., Appella, E., Kung, H., Leonard, E., Oppenheim, J. J. (1988) J. Exp. Med. 167, 1883-94.

17. Strieter, R. M., Kunkel, S. L., Showell, H. J., Remick, D. G., Phan, S. H., Ward, P. A., Marks, R. M. (1989) Science 243, 1467-69.

18. Strieter, R. M., Phan, S. H., Showell, H. J., Remick, D. G., Lynch, J. P., Genord, M., Raiford, C., Eskandari, M., Marks, R. M., Kunkel, S. L. (1989) J. Biol. Chem. 264, 10621-26.

19. Strieter, R. M., Chensue, S. W., Basha, M. A., Standiford, T. J., Lynch, J. P., Baggiolini, M., Kunkel, S. L. (1990) Am. J. Respir. Cell Mol. Biol. 2, 321-26.

20. Larsen, C. G., Anderson, A. O., Appella, E., Oppenheim, J. J., Matsushima, K. (1989) Science 243, 1464-67.

21. Strieter, R. M., Chensue, S. W., Standiford, T. J., Basha, M. A., Showell, H. J., Kunkel, S. L. (1990) Biochem. Biophys. Res. Comm. 166, 886-91.

22. Strieter, R. M., Wiggins, R., Phan, S. H., Wharram, B. L., Showell, H. J., Remick, D. G., Chensue, S. W., Kunkel, S. L. (1989) Biochem. Biophs. Res. Comm. 162, 694-700. 